\title{
Entrevista com o professor Jorge Gaspar*
}

GEOSUL - Inicialmente, agradecendo a sua atenção, gostaríamos que o senhor nos apresentasse um pouco da sua história pessoal. Diganos sobre suas origens familiares, como foi a sua infância e início de sua escolaridade e como esta escolaridade o conduziu na formação pessoal e profissional.

Prof. Jorge Gaspar - É um prazer responder a este roteiro; é bastante longo, vamos ver como nos saímos desta tarefa. As minhas origens familiares, simplificando, e para usar termos muito da Geografia, são camponesas, sobretudo do lado do meu pai. São camponesas, mas ambas nas sombras das cidades. O meu pai é natural do município de Coimbra, de uma freguesia rural, e a minha mãe é natural de uma freguesia que hoje faz parte da aglomeração urbana de Braga. Curiosamente, Coimbra e Braga - senti isso muito na minha infância em casa, as vezes, com os piques dos meus pais eram duas cidades rivais, no sentido que ambas lutavam pelo terceiro lugar na hierarquia urbana popular, comum, não uma hierarquia feita por geógrafos. Toda gente sabia que Portugal tinha Lisboa, tinha o Porto, e depois, uns diziam que era Braga, outros diziam que era Coimbra. Coimbra tinha a universidade, mas Braga tinha o arcebispo. Ambas tinham uma dimensão urbana que, de certo modo, só existia, embora em menor dimensão, na cidade de Évora, que em outros tempos tinha competido até por um segundo lugar

\footnotetext{
* Professor Catedrático Emérito do IGOT e investigador do Centro de Estudos Geográficos, Universidade de Lisboa. Entrevista realizada pelo professor Ewerton Vieira Machado, do GCN/CFH/UFSC, entre suas atividades do estágio Pós-doc, no ICS - Instituto de Ciências Sociais da Universidade de Lisboa, em 2012. Entrevista transcrita de gravação digital pelo acadêmico de Geografia da UFSC Leonardo Baccarin, voluntário do Projeto Geomemórias (GCN/CFH/UFSC). Texto revisado e autorizado a sua publicação pelo entrevistado em dezembro de 2013.
}

Geosul, Florianópolis, v. 28, n. 56, p 211-253, jul./dez. 2013 
com o Porto, nos séculos XV e XVI, mas depois, a partir dos séculos XVIII e XIX, foi perdendo esta vantagem. Braga e Coimbra, então, já tinham esta disputa. Quer dizer, os meus pais nasceram na sombra da cidade, e esta relação campo-cidade acabou por orientar as suas vidas, como muitos outros portugueses de então, no primeiro quartel do século XX. Minha mãe nasceu em 1915, e meu pai em 1911, e quando chegaram os tempos terríveis do final dos anos 1920, anos 1930, ambos tiveram que procurar trabalho em Lisboa, e encontraram-no Colégio Moderno, onde era diretor e principal proprietário o Dr. João Soares, pai do Dr. Mário Soares (expresidente da república). A partir daí, sempre mantendo esta ligação original, o meu pai resolveu estabelecer-se como agricultor, ainda dentro da cidade de Lisboa. E nisso teve algum apoio financeiro de amigos. Assim, estabeleceu-se, tendo logo o Colégio Moderno como um dos clientes, encontrando depois outros grandes clientes. Na II Grande Guerra, há grandes problemas de abastecimento da cidade e a proximidade é fundamental. Isto vai ser a sorte econômica da família, porque meu pai consegue uma produção de qualidade e quantidade e próxima do mercado. Tanto dos mercados individuais o meu pai, por exemplo, foi o fornecedor do Colégio Militar; e além do Colégio Militar, outras instâncias deste tipo, o que dava, neste tempo, um rendimento bastante interessante - como estava próximo do mercado urbano.

GEOSUL - No Colégio Moderno foi onde o senhor fez a sua escolaridade?

Prof. Jorge Gaspar - Exatamente, a Instrução Primária. A ligação inicia-se aí. Eu tive a oportunidade de lembrar alguns destes aspetos, quando fiz o discurso abonatório na imposição das insígnias de Doutor honoris causa ao Dr. Mário Soares, na nossa universidade. Isto aconteceu no ano de 2011.

Ora a atividade agropecuária deu proventos interessantes, que meu pai soube investir na compra de duas quintas na periferia de Lisboa, na Margem Sul. Portanto, meu pai tinha esta visão do que iria ser o crescimento metrópole lisbonense. Paralelamente, dedicava-se ao 
negócio de gado, o que influenciou minha tese de licenciatura ${ }^{1}$, sobre feiras de gado na Beira do Litoral. Foi algo que aprendi na infância, quando ia com meu pai frequentar os mercados e as feiras de gado. Foi uma investigação que gostei de fazer e ainda hoje creio ser um trabalho bastante apresentável. O pai teria uma ambição, de criança, ser urbanista. Mais que um urbanista, um promotor de urbanização. Gostava de sentir o crescimento da cidade, o progresso da cidade. A propósito, eu recordo, quando meu pai emigrou pra Lisboa, o meu avô emigrou para o Brasil com o filho mais velho e teve menos sorte, indo trabalhar nos caminhos de ferro em Ribeirão Preto. E então, meu pai contava muito sobre o Brasil, da dimensão do país, da importância que tinha o desenvolvimento das cidades e dos transportes. O progresso. Entender o progresso, era típico desses tempos e esteve sempre presente nas conversas com meu pai, e isso me influenciou muito.

GEOSUL - Essa influência familiar e a escolaridade foram o que o influenciou na formação profissional?

Prof. Jorge Gaspar - Diretamente. Eu recordo do meu pai, por exemplo, fazer em papel quadriculado imagens do que poderia ser o crescimento de uma cidade. Este ano mesmo (2012), em maio, estive em Presidente Prudente, e achei uma maravilha, numa conferência que fiz lá, e logo integrei no meu PowerPoint, uma descoberta que foi feita do primeiro desenho para Presidente Prudente, por um coronel que agora não me recordo o nome. Foi um dos dois coronéis que criaram a cidade. Pois era exatamente o tipo de croquis que meu pai me mostrava do que poderia ser o crescimento de Coimbra, do que poderia ser o desenvolvimento de uma cidade. Outra coisa onde meu pai me influenciou muito foi na astronomia. Eu ainda era muito criança e conhecia muitas das estrelas e constelações do céu. Tudo isso foi desenvolvendo um espírito de conhecimento do universo e também do planeta. Porque mostravam muitas das coisas que via no jornal e em mapas.

${ }^{1}$ A licenciatura em Geografia até1975 tinha a duração de 5 anos e exigia uma dissertação final sobre tema original. 
GEOSUL - O senhor é filho único?

Prof. Jorge Gaspar - Somos quatro, eu sou o mais velho. Tanto que fui favorecido na atenção que meu pai dedicou. Eu viajava muito com ele. Outra coisa que me fascinava eram os números. Eu com cinco anos de idade já sabia a tabuada toda. Então se deu a decisão de eu ir para o Colégio Moderno. Embora vindo de um ambiente que não seria propriamente burguês, eu tinha uma excelente formação. Sabia ler. Meu pai adorava ensinar, e ensinoume a ler pela Cartilha Maternal de João de Deus. A Cartilha Maternal era um livrinho com menos de cem páginas, em formato de bolso, e não tinha nenhuma imagem. Só tinha letras e palavras, e as palavras tinham diferentes letras, e o papel que estas desempenhavam nas palavras era denotado por uma diferença de intensidade, do cinzento claro ao negro; e isto funcionava. Funcionava tão bem que eu aos seis anos sabia ler o jornal perfeitamente. Mais do que isto, tinha decorado - uma coisa que estimulava este método era decorar - por exemplo, a poesia final da cartilha maternal; o poema Hino de Amor era um poema dedicado a Nossa Senhora.

GEOSUL - O senhor fala bastante do seu pai. E a sua mãe?

Prof. Jorge Gaspar - Eu sou parecido com os dois. E do lado da minha mãe, pego o gosto pela casa e o sentimento pelos pobres. Minha mãe era fantástica, de sentir o problema das pessoas. $\mathrm{Na}$ doença ou na carestia, nessa época que era difícil, embora não fossemos ricos, a minha mãe dispensava atenção aos mais necessitados. Por isto frequentavam a nossa casa. Pedir esmola era típico da Lisboa de então. Ela era muito sensível e penso que herdei isto. Era alegre também, adorava cantar; sabia inúmeras cantigas, tanto tradicionais como modernas; sobretudo, cantigas tradicionais do Minho. O meu pai não ligava tanto para estas coisas. Eles eram muito diferentes e nesses aspectos, penso que herdei de cada um, um pouco. Do melhor e do pior de cada um (risos). 
GEOSUL - Diga-nos como a Geografia do seu tempo escolar era ensinada e se essas aprendizagens o influenciaram nos encaminhamentos e desdobramentos da formação acadêmica de Geógrafo.

Prof. Jorge Gaspar - Entrei para o Colégio Moderno e, como tinha aquela habilidade de saber a tabuada, os professores me utilizavam para ir às turmas do terceiro e quarto anos interrogar os colegas mais velhos, o que não era bonito e, além disso, perigoso. Ora os primeiros quatro anos foram fundamentais para minha formação. O Colégio Moderno, neste nível de instituição primária, tinha excelentes professores, excelentes pedagogos. Tinha o diretor, o professor João Soares, que era uma pessoa extraordinária, na compreensão dos problemas e na visão que ele tinha para a escola. E tinha outra coisa fantástica: era geógrafo. Ele produziu durante muito tempo o melhor atlas escolar que existira em Portugal: o Atlas Escolar Português, uma versão portuguesa do atlas italiano da De Agostini, de Novara, mas com muitas alterações. Uma adaptação referente a Portugal e as colônias. Este atlas foi uma das minhas delícias. $\mathrm{O}$ atlas era complementado por muitos mapas, mapas de parede, planisférios, mapa-múndi, mapas de cada continente e vários mapas de Portugal, divisão administrativa, hidrografia, com os caminhos de ferro, rodovias. Todos me atraiam durante o intervalo das aulas. Comecei assim a conviver com os mapas.

GEOSUL - Isto despertava o seu interesse pela Geografia?

Prof. Jorge Gaspar - Na terceira classe, eu tinha de oito para nove anos, já conhecia todos os rios e montanhas do país, todos os municípios. Mostrava isto em concursos com os colegas, para dizer onde estava e apontar no mapa. Isto me marcou definitivamente; este contato com Cartografia. E foi por isso que eu vim para a Geografia. Quando eu tinha em torno de oito a dez anos, em 19501952, as profissões mais prestigiadas em Portugal eram as do Direito e da Medicina. Mas a nova profissão muito prestigiada era Engenharia, o que se quadrava com a ideologia do Estado Novo. O 
grande mito português, o herói, do tempo de Salazar, não era o Salazar, era o engenheiro Duarte Pacheco, que faleceu em 1943, num desastre de automóvel, ali perto de Vendas Novas, no Alentejo. Andava ele a visitar as suas obras, que iam desde a recuperação do patrimônio, às barragens, canais de irrigação, estradas, escolas. Tinha uma visão desenvolvimentista para o país, infraestruturalista. Foi o verdadeiro mito que ficou. Ainda mais tarde se dizia que se tivesse ficado aqui o Duarte Pacheco, o país teria sido outro. E, portanto, o que os jornais anunciavam de positivo eram as obras públicas. O Duarte Pacheco, que era professor do Instituto Superior Técnico, promoveu obras na cidade de Lisboa, porque foi simultaneamente ministro das obras públicas e prefeito da capital. Ele deu uma volta ao urbanismo e ao planejamento urbano na cidade de Lisboa. E, portanto, como muitas das crianças que estavam sendo sensibilizadas para o que estava a acontecer, se me perguntavam o que queria ser, eu dizia engenheiro. Mas engenheiro de mapas, porque eu gostava muito dos mapas. E, na realidade eu acho que foi aquilo que eu vim a ser, um engenheiro de mapas e um engenheiro da Geografia. Mas não fui para a Engenharia Geográfica!... Na minha família, uns queriam que eu fosse fazer Direito, outros que eu fosse militar. Enganei a todos e fui para a Geografia, como eu queria. Depois se aprofundou o gosto pela Geografia, por conhecer o mundo, por viajar no mundo.

GEOSUL - Como foi, quando e quais as lembranças que tem de sua formação em Geografia. Quem foram seus mestres e que lembranças e influências eles legaram a sua formação?

Prof. Jorge Gaspar - Claro que o ensino secundário também teve importância, embora com aspectos positivos e negativos; mas eu suplementei alguma carência do ensino básico e secundário, não só com leituras, mas também através da minha própria responsabilidade de viajar o mundo. Eu percorri o país dos catorze aos dezesseis anos, com meu irmão, a acampar e a fazer autostop, tomando carona, quando o país era outro. 
GEOSUL - Isto em que ano?

Prof. Jorge Gaspar - Primeiro foi em 1956, acampamos no Algarve, onde hoje estão grandes aglomerações turísticas, daquelas mesmas massificadas, com muitos hotéis e tudo o que caracteriza as estâncias turísticas de massas. Nós estivemos acampados em Armação de Pêra, onde o turismo mal se iniciava.

GEOSUL - Armação de Pêra, balneário que pertence ao Concelho de Silves?

Prof. Jorge Gaspar - Exatamente. É um exemplo, mas percorremos boa parte do Algarve em autostop, ajudando os pescadores que nos davam peixes. Férias fantásticas, com catorze anos. Depois, ao fazer dezessete anos, parti pela Europa e tive a mesma experiência. Todos os anos eu percorria parte da Europa, em autostop, e ficava três meses, até três meses e meio. Trabalhei em muita coisa e isso contribuiu para a minha aprendizagem de Geógrafo. Da universidade, o que eu recordo mais? O que considero o que dou muita importância, e está a se perder, o que mais gostei da Geografia na universidade, foi do trabalho de campo. O ensino na faculdade, em sala de aula, era relativamente pobre. Alguns professores davam poucas aulas; inclusive com o professor Orlando Ribeiro. Felizmente eu tinha uma relação excelente com ele e conversávamos muito. Todas as semanas eu tinha uma conversa com ele e sobre assuntos não exatamente da disciplina; sobre as coisas mais variadas. Aquilo contribuiu muito para minha formação. Nas visitas de campo, tanto na Geografia quanto na Geologia, eu tive excelentes professores. O meu segundo ano, em 1962, ano das grandes crises acadêmicas, eu tive que sair do país. Greve aos exames, manifestações políticas, curta passagem pela prisão. Depois fui procurar fazer a minha vida na Dinamarca, que já a conhecia antes, do autostop. Então em 1962, lá fui candidatar-me à universidade. E onde que eu tinha lugar para entrar? Onde é que me dariam equivalência? Em Geologia, que era o que eu sabia mais no meu segundo ano de faculdade. Pois é uma área que ainda hoje gosto muito e considero importante. 
GEOSUL - De que mestres o Senhor lembra?

Prof. Jorge Gaspar - Já falei do principal, o mestre Orlando Ribeiro. Tenho muitas coisas escritas sobre ele, inclusive de natureza mais pessoal. Como disse, ele me influenciou mais ao longo das conversas que tínhamos e foi por sua intervenção que, quando conclui a licenciatura, tive uma bolsa de estudo da Fundação Gulbenkian, através do Centro de Estudos Geográficos, para um estágio misto em Geografia econômica e Geologia. Começava então com o projeto de uma tese de doutoramento sobre a vinha do Douro. Depois tudo mudou, porque fui ser assistente em Arquitetura na Escola de Belas Artes de Lisboa, e tive que estudar e pesquisar mais a Geografia Urbana. Mas foi mais por isso, se não teria continuado na Geografia econômica e regional. A aprendizagem com Orlando Ribeiro foi decisiva a partir da minha licenciatura, no Centro de Estudos Geográficos, eu ficava até tarde para trabalhar na minha tese de doutoramento. Ele ficava até tarde também e, muitas vezes, quando saía, ele batia a minha porta. Eu, às 18:00, 19:00, quando ia sair, batia à porta dele, e ficávamos lá até às 20:00 conversando. Isso foi muito importante na minha formação. Mas voltando atrás, o primeiro contato que tive no Departamento de Geografia, foi com o professor Ilídio do Amaral, em Geografia Física. O professor Amaral era excelente. Ainda está vivo e é um dos membros eméritos da Academia das Ciências de Lisboa. Ele tem um currículo vastíssimo, talvez o mais vasto de todos os geógrafos portugueses. Ter iniciado a Geografia Física com Ilídio do Amaral foi decisivo para muitos alunos. No primeiro ano com Ilídio do Amaral, demos uma introdução à Geomorfologia e uma introdução à Climatologia. Excelente. Ainda tenho lembranças de tudo o que aprendi com ele, muito útil e muito atualizado. Deste ponto de vista, como um pedagogo nos primeiros anos, meu professor de Geografia foi Ilídio Amaral. Claro que tive outros grandes professores em Geografia, em Antropologia e em História. Em Antropologia, destacava-se Jorge Dias e em História nomes como Virgínia Rau, Veríssimo Serrão e Jorge de Macedo. 
Mas a Universidade era muito mais, a abertura cultural para a cidade e para o Mundo.

GEOSUL - Fazendo o curso e curtindo a cidade.

Prof. Jorge Gaspar - Curtindo, sobretudo, os espetáculos, teatro e cinema. Cheguei a tentar no grupo cênico da Faculdade de Letras. Comecei a fazer teatro, mas realmente eu não tinha vocação. $\mathrm{O}$ mestre, o professor Fernando Amado, amavelmente, nunca me disse para eu ir embora, mas eu percebi que o teatro não era meu caminho.

Eu tinha tempo para isso tudo. Não sei porque, o tempo rendia mais. Andava muito de transporte público e o transporte público ajudava a amadurecer as coisas...

GEOSUL - A pensar a realidade...

Prof. Jorge Gaspar - Exatamente. Mas queria voltar aos mestres! Portanto, em Geografia tive outros professores a que já tenho feito referência. O João Evangelista, que foi professor de Geografia da População, entre outras coisas, e que era um homem que tinha um conhecimento prático. Ele tinha uma carreira, ele fez uma vida de prática fora da academia e transmitia também esta maneira de estar no mundo, com entusiasmo. E também fazia muito trabalho de campo, onde saíamos todas as semanas. Às segundas-feiras, nós saíamos da cidade num Jipe do CEG, para pesquisar numa cidade pequena ao norte de Lisboa, o que foi importante pela aprendizagem proporcionada com os contatos com a realidade social e econômica.

Frequentei também muito as aulas do curso de História, tive grandes professores desta disciplina. Algumas cadeiras de Histórias eram obrigatórias, mas eu tirei outras por fora, porque me agradava muito. História Moderna, História Contemporânea, mas fui também frequentar uma cadeira que se chamava História da Cultura Portuguesa. O que era isso? Era tudo, valia tudo, o mestre foi a pessoa com mais gênio, com mais talento que conheci na universidade. Aquele com quem em aula tive as vivências mais 
fortes, vivências no sentido que o Ortega y Gasset usava o termo, aquelas verdadeiras experiências. $\mathrm{O}$ mestre era $\mathrm{o}$ professor Vitorino Nemésio, natural dos Açores e também conhecedor da História, da Literatura e da Cultura do Brasil. Ele era muito criticado porque não tinha método, porque esquecia e chegava a dar o mesmo tema em dois dias seguidos.. Os meus colegas eram, a maior parte, de outros cursos, sobretudo das Filologias Românica e Germânica, e da História também. Na Geografia, a cadeira não existia, e nem sequer se podia tomar como opção. Frequentei por três anos a mesma cadeira do professor Vitorino Nemésio. Pedia autorização para estar lá, não tinha classificação, nem certificado de presença, mas era fantástico. Vitorino Nemésio era genial. Houve uma aula que ele resolveu falar sobre o ritual do chá. Eu nunca mais me esqueci, porque ele falou desde o que era chá, onde se produzia, como que os portugueses tomaram contato, como trouxeram, as importantes negociações com a Inglaterra, a Rainha D. Catarina, etc. Quando ele acabou a aula nos disse como tomar o chá. Era fantástico!

GEOSUL - Após graduado, como e quando o senhor passou a atuar profissionalmente? Como se realizaram suas formações em pós-graduação?

Prof. Jorge Gaspar - Depois do estágio no Douro, a que já me referi, com a ajuda do professor Ilídio do Amaral encontrei um posto de assistente na Escola Superior de Belas Artes de Lisboa, Departamento de Arquitetura, onde fui ensinar Geografia Física e Geografia Humana. Foi excelente, pois tive que aprender coisas que nunca tinha aprendido na licenciatura.

GEOSUL - Foi estudar para dar aula.

Prof. Jorge Gaspar - Completamente. A parte da Geografia Humana, que era urbana, foi fácil, porque o professor Ilídio do Amaral deu-me uma lista de livros fundamentais. Por exemplo, foi ele que me introduziu a autores como Lewis Mumford (A Cultura das Cidades e A História das Cidades), Patrick Abercrombie, 
Ebenezar Howard. Na Geografia Física, eu concentrava o ensino em dois domínios principais: as bases geológicas e geomorfológicas e noções de Climatologia para os arquitetos, adaptadas à Arquitetura. Neste domínio, recordo as obras de referência que então utilizei, com proveito para docente e alunos: An Introduction to Climate, de Glenn Thomas Trewartha e Design with Climate de Victor Olgyay. Os candidatos a arquitetos sentiam, assim, a utilidade da Geografia. Eu era assistente, com duas cadeiras, tinha vinte e três anos, e passei a fazer parte do conselho escolar, do Curso de Arquitetura: muita responsabilidade e uma grande oportunidade para aprender. Os nove anos que estive como docente em Arquitetura foram fundamentais para a minha formação profissional e para a minha carreira como urbanista e planejador.

A aprendizagem formal prosseguiu na pós-graduação. Orlando Ribeiro incentivava seus discípulos a fazerem estágios, ou fazerem pós-graduações no estrangeiro. Em geral, ele indicava a França, cujas universidades eram as mais procuradas pelos geógrafos portugueses naquela época. Ora, no ano em que conclui a licenciatura, dois colegas meus ficaram como assistentes no departamento de Geografia. Pode dizer- se que eu fui o terceiro, e por isso não fiquei lá. Mas foi a minha sorte. O professor Carlos Alberto Medeiros ficou na área de Geografia Humana e o professor António de Brum Ferreira ficou na área de Geografia Física. Tiveram bolsas para ir para a França. Um foi para Clermont Ferrand, para aprofundar formação em Geomorfologia; outro foi pra Bourdeaux, que tinha uma escola excelente de estudos coloniais ou, se preferir, de Geografia das Regiões Tropicais, e que era uma coisa importante para o nosso departamento.

GEOSUL - Talvez isso por conta de como Portugal tivesse as suas influências coloniais.

Prof. Jorge Gaspar - É uma tradição. Para mim, a melhor obra monográfica do Orlando Ribeiro é, sem dúvida, o trabalho sobre a Ilha do Fogo, em Cabo Verde; estudo muito bem estruturado, 
completo, um modelo de monografia de Geografia regional, que no fundo era então o paradigma...

GEOSUL - Da Escola Francesa...

Prof. Jorge Gaspar - E também de Orlando Ribeiro. Ele mostrou que, para além da valiosa obra que já publicara em diferentes domínios da Geografia, também era capaz de fazer uma grande tese de doutoramento à francesa. Embora de início fosse apenas preocupado com o estudo da erupção do vulcão, acabou por escrever uma monografia fantástica sobre a Ilha do Fogo.

Mas, retomando a narrativa, a minha pós-graduação não foi em França. O Orlando Ribeiro sugeriu a Alemanha: "Uma pessoa favorável para você trabalhar na Alemanha era o Carl Troll" - que estava em Bonn. Mas Carl Troll praticava uma Geografia integral, cultural e regional, e eu disse: "Professor Orlando Ribeiro, eu estou na Arquitetura, tenho que fazer uma tese na área urbana". Depois ele disse: "Fui agora há poucos anos no congresso da UGI em Estocolmo, e quem apresentou coisas muito interessantes na área urbana, teve inclusive um simpósio especial com o estado da arte dos estudos urbanos, nos EUA e em outras partes, foi o pessoal de Lund". "Mas eu não conheço ninguém de Lund". "Procuramos alguém e escrevo dizendo que quer ir pra lá". Eu disse: "Lund é ótimo porque eu até falo um bocadinho de dinamarquês, e posso estudar sueco". Embora eu também soubesse um pouco de alemão, para ir para a Alemanha. E o Orlando me fez uma brincadeira, e dizia: "Olha, vá ao anuário da UGI, veja onde está Lund e escolha o nome mais esquisito, que lá houver" (risos). Fui lá e encontrei um nome muito esquisito, e o escolhi. Mas não foi por ser esquisito, e sim por ser o nome com mais prestigio internacional, mas que eu, de fato, nunca tinha ouvido falar: Torsten Hägerstrand. Ele é, para muitos dos geógrafos de todo o mundo, o geógrafo que, na segunda metade do século XX, mais influenciou o avanço da Geografia Humana. Toda a Nova Geografia foi influenciada por ele. Depois, muito da reação à Nova Geografia, incluindo a Geografia dita Humanista, sai do pensamento de Hägerstrand e de gente que 
trabalhou com ele, incluindo a Anne Buttimer. Quase todos os geógrafos, tanto ingleses como americanos, dos anos 1950 e 1960, foram influenciados por Hägerstrand. Ele estava na ordem do dia por causa da nova importância que voltavam a ter os estudos da inovação. A tese de doutoramento dele, nos anos 1950, era sobre a difusão de inovações, o que no fundo era trazer para a Geografia toda a teoria da difusão das inovações no espaço. Mas depois, com o aparecimento dos computadores, ele consegue introduzir a Teoria dos Jogos no estudo de difusão de inovações. Os seus primeiros ensaios sobre o Método de Monte Carlo são aplicações aos processos migratórios: a difusão da imigração, os movimentos pendulares.

Lund e Uppsala são as universidades históricas da Suécia. A de Uppsala é a universidade mais antiga do que era o reino da Suécia, do século XVI. O reino da Suécia alargou-se no século XVII, quando os suecos conquistaram ao sul a Escânia, que era uma província dinamarquesa. E, portanto, era estrategicamente importante suecizarem o território, trazê-los para a Suécia. Para além de anexar militar e politicamente, era preciso fazer uma integração, não só econômica mas, sobretudo social e cultural. Para isso, promoveu um novo desenho administrativo e, mas, sobretudo, criaram uma universidade. E essa universidade vai ser criada onde estava aquilo que era o ponto cultural mais importante desde a idade média: a catedral de Lund. Você pode ver a catedral e um pouco do ambiente de Lund em um filme famoso do Ingmar Bergman, chamado "Morangos Silvestres". Mostra bem a ideia da academia e de sua ligação com a Igreja, que na Suécia durou até muito tarde.

GEOSUL - E sua tese neste doutorado foi sobre o que?

Prof. Jorge Gaspar - Fui para lá fazer uma pós-graduação, que deveria conduzir a um mestrado, num tema a decidir com Hägerstrand. Ao ver meu currículo - eu tinha uns artigos não publicados, mas já escritos, mas tinha uma dissertação de licenciatura que mostrei - ele disse: "Mas isso é uma boa dissertação de mestrado, você não tem que fazer mestrado aqui; 
você vai se inscrever no doutoramento". Os cursos do doutorado eram quase todos em inglês; os seminários, que não eram muitos, traziam professores de todo o mundo. Tinha colegas de vários países, de belgas a quenianos, e havia um ambiente muito bom. Tínhamos visitantes como o Peter Haggett ou o Peter Gould, com o qual estabeleci uma grande amizade. O Alan Pred era outro visitante frequente. E mesmo em 1967, eu ainda ouvi uma conferência do Walter Christaller - uma conferência que, já muito perto do fim da carreira, ele repetia - em que mostrava como ele chegou à Teoria dos Lugares Centrais. Christaller sempre errou na vida em relação às suas opções políticas e assim foi muito ostracizado depois da Guerra, teve problemas econômicos, dificuldades, e Hägerstrand o ajudou, como ajudou em outros sentidos a outras pessoas.

Em Lund, tive ainda intensos contatos com vários geógrafos nórdicos. Torsten Hägerstrand quis que eu visitasse as universidades da Dinamarca e da Suécia, e também a de Oslo. Pela proximidade, aprofundei mais os contatos com a Universidade de Copenhague, que se mantiveram ao longo de quatro décadas.

Em Lund, não posso deixar de recordar o professor Edgard Kant, um estoniano, da Universidade de Tartu, a segunda cidade da Estônia. É uma cidadezinha pequena, junta a um lago. O Edgard Kant foi recebido por Hägerstrand como refugiado. Depois da II Grande Guerra, os três países bálticos, entre eles a Estônia, foram integrados à URSS. O Edgard Kant estava muito avançado no pensamento geográfico que interessava e era relevante na época. Ele chegou a produzir algo muito semelhante à Teoria dos Lugares Centrais, antes do Christaller, e era um homem que tinha um grande conhecimento do mundo e da Geografia no mundo; falava umas sete línguas. Ficamos muito amigos, porque ele gostava de me receber em seu gabinete, no fim da tarde. Ele tinha muito gosto em falar francês e não tinha muitas oportunidades. Então, para falar francês comigo, falávamos de Geografia. Ele foi dessas pessoas que me influenciou em muitos aspectos, incluindo na maneira do estar no mundo. Este foi um grande mestre, Edgard Kant! 
GEOSUL - Isso no seu doutorado?

Prof. Jorge Gaspar - Isso no âmbito do doutorado, que comecei fazer de que o tema da dissertação final já estava definido: "Évora e a sua região". Foi sugerido por Orlando Ribeiro, numa perspectiva muito da geografia francesa.

GEOSUL - Sabe-se que o Prof. Orlando Ribeiro foi a grande referência para a formação de uma Geografia acadêmica e profissional em Portugal. Fale-nos sobre esse grande geógrafo e o que ele representa também em sua particular trajetória.

Prof. Jorge Gaspar - Orlando Ribeiro era ao mesmo tempo muito aberto a novas orientações, mas em certas questões podia ser intransigente. Durante algum tempo, depois da minha ida para a Suécia, houve alguma "tensão" na minha relação com Orlando Ribeiro, no plano científico. Uma relação tensa, mas criativa. Ele queria saber tudo o que eu fazia. E consegui fazer um plano, que era manter a minha rota na geografia francesa, com uma componente histórica, mas depois abrir para a Nova Geografia, para os métodos quantitativos, para o uso do computador. O primeiro artigo quando se fala hoje de SIG e de cartografia automática, publiquei na Finisterra com o Hägerstrand. Foi publicado em 1969. Mas, ao mesmo tempo, publiquei um artigo sobre a cidade muçulmana e outro sobre as plantas geométricas das cidades medievais. Pesquisas desenvolvidas em Lund, a primeira a partir de trabalho de campo que levei a cabo em Marrocos em 1966, a segunda a partir de uma visita de estudo que fiz com Orlando Ribeiro em Portugal, em 1967; ou seja, ao mesmo tempo em que trabalhava na Teoria dos Lugares Centrais e suas atualizações, mantinha o interesse por temas mais "clássicos". Isto foi possível em Lund porque tinha acesso, a partir da biblioteca da Universidade de Lund, a grandes bibliotecas, como a Biblioteca Nacional de Espanha, em Madrid, ou a de França, em Paris. Os acordos de intercambio permitiam que em menos de duas semanas, obtivesse livros ou revistas por empréstimo. Não era internet, era o correio, mas funcionava. 
Entretanto, Orlando Ribeiro achava muito estranho todo o meu empenhamento em relação à teoria de Christaller; ele não gostava nada do Christaller. Mas eu continuei sempre a fazer-lhe relatórios sobre os progressos do meu trabalho, que também se destinavam a apresentar na Fundação Calouste Gulbenkian, que me concedera a bolsa de estudo. Um dia ele escreveu-me: "Não há uma tradução deste Christaller"? Mandei uma, em inglês, e ele passou a escrever coisas, a atacar o Christaller, na Finisterra. Na altura, achei algo despropositado, mas depois compreendi a grandeza da sua reação. Aí que foi a "nossa disputa". Enfim, chegávamos às mesmas conclusões por vias diferentes. Há uma dimensão de necessidade, geométrica na Geografia, embora o mundo seja muito mais... Hoje, isto é pacífico. Conseguimos conciliar as duas coisas. Infelizmente a Geografia, e isto é um aparte meu, tem perdido este saber de conciliar a geometria com a dimensão do acaso. Há necessidade e acaso. O poder da Geografia, a sua força, é estar além do social. Ela é social, mas também é uma ciência relacionada com a natureza e tem muito a ver com a componente matemática e geométrica.

GEOSUL - Isto como ferramenta de meio, ou como fim?

Prof. Jorge Gaspar - Como fim, como meio e como princípio, tanto no plano analítico como no plano conceitual. Qual é o fim último de um trabalho científico? É simplificar a realidade de maneira a compreendê-la. E o que é isso? É o modelo. Este modelo pode ser feito em duas frases muito bonitas, mas ele é mais fácil e mais claro, muitas vezes, através das fórmulas que a matemática nos proporciona: equações e formas geométricas. A Geografia muitas vezes está a se confrontar com a Sociologia, e mesmo com a Psicologia, a Antropologia, e não tinha que se confrontar com elas; ela tem a sua própria razão de estar. Tem o seu objeto e que é enorme. Seu objeto e seu método. Então, no que toca ao Orlando Ribeiro, ele tinha uma qualidade, que era resistir, o que é importante. Resistir às inovações que os discípulos querem introduzir. Mas este resistir dele era uma forma de estimular. Se você fosse persistente e ele visse que você era sério, e o que estava a fazer tinha relevância 
científica, ele podia não se alinhar, mas dava incentivo e apoio. Eu tive esta sorte; não tiveram outros colegas meus. Ele contrariou certas orientações e em algumas delas ele não tinha razão. Mas se as pessoas se moldavam ou se tornavam mais dúcteis, o Orlando Ribeiro não apreciava tanto. Portanto, a minha relação com ele, por vezes, no plano científico - pois no plano da amizade foi sempre excelente -, foi tensa. E isto o estimulou, porque ele produziu, investigou, publicou artigos, para contrariar algumas das coisas que eu seguia e isso é excelente. É o verdadeiro diálogo e isso marcou-me positivamente. Creio que aprendi a proceder do mesmo modo com os meus alunos e isso eu aprendi com o Orlando Ribeiro. Isto eu tenho falado, mas nunca escrevi. Mas é um fato. O Orlando Ribeiro não era aquela pessoa que estava a toda hora disponível. Ele procurava orientar, controlar e depois suportava o contraditório. E era preciso demonstrar, por exemplo, a ponto de ele dizer para eu lhe enviar o livro do Christaller, que ele queria ver como é que aquilo era e depois criticar.

GEOSUL - Ainda com base nas ideias do Prof. Orlando Ribeiro qual a sua opinião a respeito dessa liderança, na condução de um pensamento geográfico na orientação, formação e atuação, no período em que Portugal esteve sob a ditadura de Salazar, que coincide com o nascedouro da Geografia institucional, via o Centro de Estudos Geográficos na Universidade de Lisboa? É grande esta pergunta, mas... ... faça seus recortes.

Prof. Jorge Gaspar - É grande e muito complexa. Por experiência própria, sei que não é fácil fazer carreira academia numa ditadura, e poderia dizer que o Orlando Ribeiro não era um homem muito empenhado na política. Passou a ser depois da crise de 1962, muito por influência de outro professor da faculdade esse, sim, com uma linha política dos católicos progressistas. Era um homem que o Orlando Ribeiro admirava muito: o professor Lindley Cintra. Era professor de linguística. Por outro lado, o filho dele, hoje professor aposentado da Faculdade de Ciências, que é um grande geólogo, Antonio Ribeiro, teve uma militância ativa. Ele foi muito ativo nos 
movimentos acadêmicos em 1962, estando inclusive preso. Orlando Ribeiro, nesta altura, estava dando aulas no Canadá, na Universidade de Laval, no Quebec. Quando voltou do semestre de aulas no Canadá, na primavera de 1962, a revolução estava instalada na universidade, e ele aí tomou a posição dos estudantes, contra o governo. Havia um homem muito forte do regime de Salazar, mas que tinha uma orientação diferente no momento. Era um grande mestre do Direito, professor da Faculdade de Direito, e estivera como reitor da universidade: o professor Marcello Caetano, futuro primeiro-ministro; de quem se esperou muito, daí a expressão "Primavera Marcelista". O Orlando Ribeiro tinha uma relação com ele que não era de amizade, mas era de mútuo apreço. O Professor Marcello Caetano de algum modo o tinha apoiado, inclusive na sua ligação à África, e Orlando Ribeiro tem isto escrito.

GEOSUL - Mas neste período da ditadura ele conseguiu implantar o CEG.

Prof. Jorge Gaspar - O CEG é anterior, dos anos 1940. Mas é preciso perceber como as coisas aparecem, porque o CEG é fundado em plena Guerra, tempo em que a Geografia adquire relevo e atualidade. E Orlando Ribeiro quis mostrar a importância da Geografia, que era uma disciplina que estava muito pouco valorizada, porque tinha maus professores. Orlando Ribeiro queria criar qualquer coisa e cria fora da Faculdade. Foi num pequeno apartamento, num prédio antigo, próximo da Faculdade de Letras, para fazer investigação em Geografia, e é aí que ele começa com um grupo muito pequeno. Mas depois da Guerra, Portugal vai ter que enfrentar o grande problema de salvar a ditadura; como se sabe, depois da II Grande Guerra todos os ditadores caíram, com exceção de Franco e Salazar. Salazar de uma forma muito mais airosa, porque fica na órbita anglo-saxônica; já não só da Inglaterra, mas também dos EUA, porque cedeu, a tempo, a base dos Açores aos americanos. Assim cria-se o caminho para uma abertura de Portugal, que tinha um problema maior com as 
colônias, uma cobiça para todos. Portugal vai entrar para a OTAN muito cedo e isto é importante. O alargamento do poder político e militar, estratégico, abre sempre lugar à Geografia, de uma maneira explícita ou implícita, porque os saberes geográficos são fundamentais. É preciso conhecer o que são as colônias, é preciso perceber a cartografia do mundo e das suas relações, para poder definir estratégias ao nível mais global. Portanto, a Geografia ganha importância. E na Geografia quem é que tínhamos? Orlando Ribeiro. Tanto que vai ser convidado, pelos conhecimentos que tinha e porque podia providenciar certo número de intervenções.

GEOSUL - Esse convite feito por quem?

Prof. Jorge Gaspar - Decerto pelo Ministério da Educação.

GEOSUL - E ele foi ser catedrático da Universidade de Lisboa?

Prof. Jorge Gaspar - Sim. E com todo mérito. Mas era uma forma de atuar. Havia a necessidade de tal conhecimento geográfico, sobretudo para promover um conhecimento melhor das colônias. E é a partir daí que a Geografia vai ganhar importância. Sobretudo em Lisboa, com Orlando Ribeiro e um grupo pequeno.

GEOSUL - Quem era basicamente este grupo?

Prof. Jorge Gaspar - Primeiro foi o Orlando Ribeiro com a discípula Raquel Soeiro de Brito, a que se veio juntar Francisco Tenreiro, oriundo dos Estudos Coloniais e da Ciência Política, foi deputado do Regime, mas era um homem de grande abertura; era um mestiço de São Tomé e Príncipe e fez uma tese de doutorado em Geografia sobre São Tomé e, digamos, foi o mais cosmopolita dos nossos professores - foi meu professor também. Mas não tinha muito apreço pela Geografia, digo eu. No meu entender, ele era antes de tudo um poeta.

A partir do momento em que Portugal foi aceite pela ONU, acentua-se a necessidade do melhor conhecimento das colônias, e então são muitos os que vão para lá, entre eles, Francisco Tenreiro, Raquel Soeiro de Brito, Mariano Feio e Ilídio do Amaral e outros 
que não são geógrafos, por exemplo, antropólogos, como o Jorge Dias. Todos estes professores com condições de contribuir para a abertura da África. E os estudos da África se processaram em Cabo Verde, Guiné, São Tomé, Angola e Moçambique e também nos territórios coloniais da Ásia - em Goa, aqui com o Orlando e a Raquel Soeiro de Brito, que viria ainda a desenvolver investigações em Timor e em Macau. Todas as colônias foram abrangidas por estudos, e alguns deles de grande valor. Isto durou até os anos 1970 e fez com que hoje em dia sejam facilmente recuperados. Algumas colônias nunca interromperam a licenciatura em Geografia, como na universidade de Lourenço Marques, hoje Maputo, desde a sua fundação, no início dos anos 1970. Angola, e agora Cabo Verde, também têm licenciaturas em Geografia.

GEOSUL - Após 1974, com as mudanças processadas pela "Revolução de 25 de Abril", como o senhor avalia a participação dos geógrafos portugueses nesse novo momento da vida nacional? Sabe-se que houve imensas aberturas na profusão de ideias e participações plurais, em todos os campos no processo de redemocratização portuguesa. $\mathrm{Na}$ área da Geografia houve significativa inserção e contribuições? Diga-nos um pouco sobre esse período e o que dele a Geografia e os geógrafos portugueses emprestaram contribuições.

Prof. Jorge Gaspar - Isto tem várias partes e múltiplas pontas por onde segurar; seria tema para ser abordado não só por mim. Seria, por exemplo, interessante introduzir aqui a leitura e a memória de antigos alunos, como por exemplo, o João Ferrão, que você conhece bem. Poderíamos começar com o nosso primeiro encontro na Faculdade. Era ele aluno do primeiro ano, um ou dois anos antes dos " 25 de Abril". E eu o convidei para colaborar no nosso projeto de investigação sobre estudos urbanos, lá no Centro de Estudos Geográficos. Eu terminei meu doutorado em 1972 e tinha ganhado certa autonomia e peso, e o João Ferrão estava lá um dia em volta dos mapas. Chamou-me a atenção. Ao contrário da maior parte do quadro dos jovens alunos de Geografia, que vinham da província, olhava-se 
para ele e via-se que era um urbanita, que vinha da cidade. Esta integração precoce no trabalho de pesquisa do CEG, que passou com vários jovens, contribui decerto para o bom ambiente entre os corpos docente e discente.

Por outro lado, como geógrafos estávamos mais atentos e envolvidos em várias mudanças que ocorriam no país, o que em certa medida relativizava o que se passava no interior da Faculdade e da Universidade. De fato, eu diria que ocorreram várias revoluções ao mesmo tempo. Há uma revolução que significa a passagem da ditadura para a democracia, mas as outras foram igualmente importantes. Recordo aqui um caso que se situa no extremo oposto da vida acadêmica, mas muito afim das preocupações dos geógrafos. Pouco tempo depois da revolução, visitava uma aldeia nas montanhas do centro interior, no distrito de Viseu, perto do Douro, Vila Cova a Coelheira, na Serra do Leomil. Chamou-me a atenção - nunca tinha estado lá -, o fato de a aldeia estar organizada por bairros, que é uma coisa rara, porque bairro costuma ser uma divisão de algumas cidades. Estavam por ali uns rapazes do bairro da Judiaria, "onde vivem os judeus". Estamos em 1978, ou algo assim. "Vivem lá os judeus"? "Sim, os judeus". "Mas são mesmo judeus"? "São". "Mas eles ficaram junto com os outros". "Não, só casam entre eles". "Não, depois dos "25 de abrill" já houve casamentos entre judeus e cristãos". Você veja, uma aldeia que guardou estas práticas ao longo de séculos, até depois do " 25 de Abril" e é a abertura política e cultural proporcionada pelo movimento popular que gera as condições para a aproximação entre as duas comunidades.

GEOSUL - Chegou a este grau de abertura?

Prof. Jorge Gaspar - Este aqui é um hiato de cinco séculos Inquisição, expulsão dos judeus; volto a 1500 . Como isto há muitas outras coisas: certos filmes nunca tinham vindo a Portugal até à revolução, as mudanças no papel da mulher, não tanto na vida econômica, mas na vida pública. Na vida econômica, a mulher tinha um papel importante, sobretudo nos campos, porque os homens 
emigravam e as mulheres ficavam com a economia da família. O " 25 de Abril" correspondeu a várias revoluções ao mesmo tempo. $\mathrm{Na}$ Geografia foi um pouco isso também, porque, parece absurdo, mas em 1974, noutros países, já se estava criticando a Nova Geografia, mas aqui ela estava em expansão ainda. Novamente, temos que introduzir Marx os modelos estocásticos e ao mesmo tempo, começamos a falar das questões do humanismo em Geografia.

O número de alunos que entravam no curso de Geografia, antes e depois de 1974/1975, passou de dez ou quinze para cento e cinquenta. A mesma coisa que aconteceu com o ensino, na escola básica, aconteceu na universidade e aconteceu dentro da Geografia. A diversidade aumentou e com isso nós tínhamos, no nosso departamento de Geografia, todas as orientações políticas e, talvez também por isso foi o único departamento da nossa faculdade em que não houve expulsão de professores. Por quê? A resposta politicamente correta é que nunca tivemos professores autocratas, professores corruptos, professores do Regime. Mas outros departamentos também não tinham, e, no entanto... o fato é que a Geografia tinha se mantido mais neutra e tinha tido oportunidades de investigação... Eram poucos alunos. Tinham sempre a oportunidade de emprego, pois havia falta de professores de Geografia. Havia uma carência enorme. Em algumas escolas do país chegavam a ser pessoas que tinham o "ginásio" que iam dar aula de Geografia. E poderiam fazer o curso. Portanto, havia todas estas posições, e este ambiente era politicamente "neutro", tendencialmente, claro, pois dentro do departamento, criticava-se o governo. Mas era inócuo.

GEOSUL - Que contradição! Mas de certo modo se beneficiavam deste Estado ditatorial. Por terem se mantido neutros. Não quer dizer que no Brasil também não foi assim...

Prof. Jorge Gaspar - Claro. Podemos ver casos no Brasil como em Portugal. Também tem a ver com as oportunidades; a oportunidade pode ser a chave, "faz o ladrão e faz o cidadão". É muito fácil criticar o ambiente ou certos comportamentos, agora, 
há limites. Nós, dentro da Geografia da Universidade de Lisboa, no plano interno, optamos pela continuidade, o que não significa que não houvesse por parte dos estudantes tentativas de sanear (expulsar) alguns professores. O fato de nada disso ter acontecido se deve a algumas pessoas, inclusive a mim, e estou muito feliz por isso. Não aconteceu porque não se justificava.

$\mathrm{Na}$ Geografia há sempre oportunidades para seguir vários caminhos. Na Geografia portuguesa pós "25 de abril", se desenvolveram linhas de orientação marxistas, mas também humanistas, e também quantitativistas, da Nova Geografia. E até, por exemplo, juntar Marx com a Nova Geografia. Não seguíamos uma cartilha, do Lefebvre ou do Lacoste, por exemplo. Tinha outros geógrafos, franceses e de outros países, que seguiam outras orientações metodológicas ou as mesmas orientações teóricas, e politicamente diferenciadas. Vários. Nós tanto apoiamos e quisemos ter entre nós colegas americanos e, sobretudo, inglesas, da Nova Geografia, quanto da esquerda trabalhista inglesa. Esta foi a nossa grande ligação depois do " 25 de Abril", eu diria mesmo, a mais importante. A nórdica também teve peso.

Mas tivemos também um fecundo diálogo com colegas mais conservadores, como o Paul Claval. Portanto, nós tivemos orientações pluralistas, e quisemos manter o nosso rigor e nos projetarmos como profissão. Éramos poucos, mas quisemos deixar de ser apenas formadores de docentes para o secundário. Assim, passamos a ter um papel cívico e político mais alargado, o que foi muito importante.

GEOSUL - Como o senhor situaria uma "Escola Portuguesa de Geografia", a partir dos principais centros de formação, e suas inserções no cenário europeu e até mundial?

Prof. Jorge Gaspar - É interessante você dizer a Escola Portuguesa de Geografia. Nós por vezes falamos da Escola de Lisboa e da Escola de Coimbra, embora de fatos no plano teórico e nas práticas do ensino e da investigação nada as distinguisse, ambas tinham nos mestres franceses como De Martonne e Vidal de La Blache as grandes 
referências. Hoje o panorama é diferente, não só porque há mais unidades de ensino e investigação, como há maior diversidade: os departamentos de Geografia das universidades do Minho, do Porto, de Coimbra, de Lisboa e da Nova de Lisboa têm as suas especializações e ligações internacionais privilegiadas A Geografia portuguesa e, sobretudo Lisboa, foi muito valorizada no momento histórico de 1949, data do Congresso Internacional da UGI, realizado em Lisboa, e cuja realização com meios muito escassos foi como que um milagre de Orlando Ribeiro. Depois, no âmbito regional, a Geografia vai ser um pouco esquecida. E eram muitas as relações internacionais de Orlando Ribeiro e de da Raquel Soeiro de Brito; mas, sobretudo, do Orlando Ribeiro. Coimbra, que teve bons professores, o Amorim Girão foi um grande professor, como o foi o Alfredo Fernandes Martins, um homem cheio de talento e de gênio que não deixou a obra que era de se esperar, mas foi um dos grandes geógrafos portugueses do século XX. Todavia nunca teve projeção internacional, mas influenciou bastante a geografia portuguesa do seu tempo, tendo contribuído para a continuidade da geografia de qualidade em Coimbra, tanto na vertente da Geografia Urbana, com J.M. Pereira de Oliveira, como na Geografia Física, com Fernando Rebelo.

Depois dos "25 de Abril", todos nós, do Porto, de Coimbra ou de Lisboa começamos a ir mais a congressos. Com o fato de ter havido a revolução, passaram a nos solicitar muito, pois queriam nos ouvir. Direi agora sobre meu caso pessoal. Depois dos " 25 de Abril" achei que era oportuno fazer um estudo geográfico das eleições, e assim constitui um grupo de gente jovem, geógrafos e outros, em cujas práticas convergem os métodos quantitativos com orientações teóricas de raiz marxistas e neomarxista.

GEOSUL - Já há um híbrido destas duas tendências para a Geografia.

Prof. Jorge Gaspar - Exatamente. Assim aconteceu com os estudos de Geografia Eleitoral que se iniciaram com o livro que publiquei em 1976 com Nuno Vitorino e que foi um best-seller, chamou-se As eleições do 25 de Abril - geografia e imagem dos 
partidos. Pela mesma altura, organizamos uma reforma profunda do currículo da licenciatura; sobretudo a partir de Lisboa, mas seguido pelos outros departamentos. Ocorreu no sentido de uma "Geografia Ativa", como diria o Michel Philliponeau, ou de uma Geografia Aplicada, se preferir; de uma Geografia ao serviço da comunidade... Eu colaborava com a Arquitetura e com o Urbanismo, como consultor, desde 1968. Mas não era um caso isolado, pois se tinha aberto muito a Geografia, por exemplo, com os Sistemas de Informação Geográfica. Ainda no tempo do Marcello Caetano, houve um grande projeto - Sines, que foi muito importante como experiência. No grupo de estudos para a nova cidade e o novo porto de Sines integramos uma boa meia dúzia de geógrafos que profissionais colocados ao nível dos arquitetos e dos engenheiros, e fizeram escola. Temos hoje, desses novos geógrafos, alguns gestores públicos. Os mais novos, da geração que veio a seguir, tiveram boas teses, as quais fizeram com orientações muito diferentes. Desde a tese do João Ferrão, que é mais neomarxista, mais no cruzamento das Ciências Sociais, mas com uma forte dimensão geográfica: ele antecipou a importância de olhar o território de uma perspectiva neomarxista. O capital valoriza o território e as infraestruturas, como hospitais, os transportes. Quer dizer, uma Geografia orientada por questões muito mais sociais. A desigualdade na habitação e a segregação do espaço urbano, por exemplo, são coisas que se estudou muito nesta altura. Também, orientando já para o que seria o futuro, inclusive em termos de empregos, se estudou a Geografia do Consumo. Quem vai dar depois uma orientação a esta linha é a Teresa Barata Salgueiro, que atribuiu grande peso e importância à Geografia Urbana. Ora isto começou um pouco antes do "25 de Abril".

GEOSUL - E depois do " 25 de Abril"

Prof. Jorge Gaspar - Explodiram várias linhas. Porque havia muita gente, muitos novos alunos, e com qualidade. 
GEOSUL - E ela se tornava expressiva em termos europeus e mundiais?

Prof. Jorge Gaspar - Esta Geografia entrou em muitas redes internacionais. Redes de investigação de vários os países da Europa, e alguma coisa dos EUA. E houve uma falha grande, por culpa dos dois lados, que foi não haver uma ligação maior ao Brasil. Só o nosso departamento tinha relação com quase todos os países da Europa. Tínhamos projetos com a Espanha, que eram até mais antigos; com a Itália, também antigos, desde os anos 1950; com a Inglaterra; com a Alemanha, muitíssimo também; com os nórdicos, com a Noruega, a Suécia e a Dinamarca; com a Suíça também. Passamos a ter também representações e a realizar trabalhos de consultoria para a OCDE, por exemplo. Éramos chamados para muitas coisas, pois Portugal estava na moda. E a Geografia da Universidade de Lisboa aproveitou esta onda. Nós éramos convidados para fazer, por exemplo, conferências para falar da revolução e da Nova Geografia no país; o que aconteceria ao território, às cidades, entre outras coisas. Eu diria que a relação mais forte, que se acentuou, foi com a Inglaterra. Até hoje.

GEOSUL - Uma reafirmação de identidade com a Inglaterra.

Prof. Jorge Gaspar - Exatamente. A Inglaterra fazia a melhor Geografia e não sei se não continua sendo assim.

GEOSUL - Mais que a Francesa?

Prof. Jorge Gaspar - Sem dúvida. Não tem comparação. A francesa atualiza-se indo atrás da inglesa; pessoas como Jacques Lévy ou Denise Pumain, para citar nomes que são hoje salientes. Há uma Geografia francesa, claro, que ficou e ficou muito bem. É o caso do Claval, que continua vivo e com boa saúde mental. A geração que vem logo a seguir é muito francesa, como o Frémont e o Dollfus. São homens de grande gabarito, já influenciados pela Geografia anglo-saxônica. Na Geografia inglesa sempre houve uma interação com a França. Um dos maiores nomes, que para muitos é o criador da "sociologia eleitoral", é um geógrafo dos anos 1920. Ele escreveu aquele famoso ensaio sobre o voto do granito e o voto do calcário. Agora, vou dar um indicador da 
nossa ligação com essa gente. Em 1987 nós organizamos um dos primeiros PIC ERASMUS que houve em Portugal, com um sucesso enorme. Tanto que em 1988, o jornal francês Libération promoveu o ranking das universidades europeias, por cursos (como os atuais do Financial Times). Os resultados foram apresentados em grupos de 10 instituições, o top ten dentro de cada domínio, como Química, Medicina, Matemática, etc. Só apareceu nesse top ten um curso português, que foi o do nosso departamento. As pessoas vinham felicitar, e eu dizia que gostaria também que tivesse sido escolhida a Medicina, a Física, a Química. Mas foi a Geografia...

GEOSUL - De certo modo, percebe-se certo distanciamento na trajetória da Geografia moderna portuguesa com relação aos centros brasileiros, que surgiram e se desenvolveram quase que concomitantemente aos de Portugal, na primeira metade do século XX. É possível dizer que a Geografia portuguesa estava mais voltada à realidade europeia? Que escolas europeias foram determinantes no pensamento e nas práticas geográficas acadêmicas em Portugal?

Prof. Jorge Gaspar - O distanciamento com o Brasil... Claro que o que você disse é corretíssimo, porque se desenvolvem simultaneamente. E ambas têm uma dupla cepa, e a principal é a francesa, com Mombeig e Deffontaines. Mas a segunda é alemã, assim como entre nós, também. O Lautensach e outros que se seguiram, até aos nossos dias. Vocês também tiveram uma influência alemã significativa.

GEOSUL - Talvez, mais no Rio de Janeiro, em São Paulo é mais a francesa.

Prof. Jorge Gaspar - O que é fato é que houve nesta época, anos 50 e 60, uma aproximação através do Orlando Ribeiro. Ele tinha um papel muito importante nas relações luso-brasileiras. Ele regularmente fazia sua visita, com mais frequência ao Rio e a Salvador e, por outro lado, nos anos 60, vieram alguns bolsistas brasileiros, de qualidade, estagiar no nosso Centro de Estudos 
Geográficos. Vieram também professores como Orlando Valverde ou Antônio Penteado.

GEOSUL - Ele foi honores causa no Rio de Janeiro.

Prof. Jorge Gaspar - E ele conhecia toda aquela geração. Depois retomei essas ligaçoes em 1974. Fui encontrar muitos amigos de Orlando Ribeiro, como o casal Bernardes, o Ab' Saber, o Pinchas Geiger, entre outros.

GEOSUL - E o Prof. Manuel Correia?

Prof. Jorge Gaspar - Com o Manuel Correia não andava tanto, mas o Milton Santos sim, eu conheci muito cedo. E ele conhecera o Orlando Ribeiro mais cedo ainda, embora eles tivessem "divergências"...

GEOSUL - Não se bicassem (risos).

Prof. Jorge Gaspar - E era mútuo (risos).

GEOSUL - Ele polarizava.

Prof. Jorge Gaspar - Não era só isso. Devo lembrar que a Professora Raquel Soeiro de Brito também vai ao Brasil, embora não tivesse o mesmo impacto de Orlando; não consegue ter a mesma sequência. E são coisas esporádicas, como as conferências, as visitas de estudo, os congressos. Porque não há condições, creio que de nenhum dos dois lados. No lado português, não há porque não havia pessoas. No lado do Brasil, havia muito mais força que aqui, mas estava muito pulverizada, o que não era suficiente para dinamizar uma relação. Ainda por cima com um zero, pois não havia nada deste lado.

GEOSUL - O senhor acha que Portugal era mais zero que o Brasil?

Prof. Jorge Gaspar - No sentido de haver menos pessoas, num sentido de escala. Não há pessoas em numero suficiente para 
estabelecer maiores interações. Não poderíamos ter mais ligações, com Salvador, São Paulo, Brasília, Porto Alegre.

GEOSUL - Pernambuco.

Prof. Jorge Gaspar - Pernambuco era muito conhecido, importantíssimo. Mas não houve contato praticamente, embora Orlando Ribeiro tivesse dado aulas ou feito conferências em muitos destes sítios. E também, a Geografia brasileira, durante a ditadura, tem grandes oportunidades. $O$ poder favorece a Geografia. E o Chile ali ao lado mostrava bem o exemplo. O poder de então leva a todos os estudos que se fazem sobre a Amazônia e também à abertura aos grandes modelos.

GEOSUL - Mandar o pessoal para os EUA?

Prof. Jorge Gaspar - Exatamente. Pois estava mais próximo, com mais força, e com interesses. O estado da arte estava nos EUA. Recupera-se uma ligação que já era antiga, à Califórnia, com Hilgard O'Reilly Sternberg em Berkeley; mas vão se encontrar novas posições, no Wyoming, em Chicago. O Brian Berry vai ao Brasil no início dos anos 1970, e isto tem um grande impacto. O Brasil estava mais interessado nesta ligação mais próxima, porque o país também não acompanhou muito a ligação à Espanha. Esta ligação vai ser muito forte depois da ditadura, porque os espanhóis abriram as portas. Os espanhóis tinham, e continuam tendo, uma visão hegemônica em relação à América Latina. Em vários domínios, como Portugal não podia ocupar esse espaço de parceiro privilegiado, eles ocuparam. O geógrafo da Península Ibérica que maior audiência conseguiu no Brasil foi o meu grande amigo Horácio Capel. Ele achava muito estranho porque os portugueses não se interessavam mais pelo Brasil. Nos anos 1970, até os 1990, o estado da arte da Geografia em Portugal era pelos menos tão avançado como em Espanha. Embora fossemos em menor número, e isso se via nos congressos ibéricos que criámos na segunda metade dos anos 70. Embora fossemos muito menos, tínhamos redes de influência; por causa da língua inclusive. Todos os 
geógrafos portugueses falavam inglês; os espanhóis não falavam muito línguas estrangeiras nesta altura.

GEOSUL - Vocês estavam mais próximos da influência inglesa do que os espanhóis?

Prof. Jorge Gaspar - Sim. Embora houvesse exceções, e uma delas era o meu amigo José Estéban Álvarez, que faleceu muito cedo. Este sim sabia inglês, e promoveu a tradução de livros ingleses. Os espanhóis tinham uma coisa que facilitava muito: as traduções. Porque tinham mercado. Nós tínhamos que ir aos originais.

GEOSUL - Então é por isso que a Geografia portuguesa estava mais voltada para a Europa, e o Orlando Ribeiro, portanto, sendo esta mediação?

Prof. Jorge Gaspar - Sim, claro e muitos outros que se seguiram até hoje. Por outro lado, como a projeção da Geografia depois de 1974 é muito grande aumenta a ajuda de estrangeiros que vêm investigar e ensinar em Portugal. Alem de Susanne Daveau, Bodo Freund, Allan Williams, Patrick O'Flanagan, Peter Weber, Antoinne Bailly, Chris Jensen-Butler, Paul Claval, entre muitos outros. Para mim, para a geografia que eu posso representar, há um nome incontornável: Chris Jensen-Butler. O conheci em 1973, com Peter Gould, em Lund, num colóquio europeu promovido por Hägerstrand e por Gould. Ele era do Partido Comunista Dinamarquês, e depois passou para o Socialista. Chris nasceu numa área operária da Inglaterra, Derby, e estudou em Durham. Quando acaba o curso universitário, vai dar aula em Aarhus, na Dinamarca. Tinha uma excelente formação em ciências sociais, em particular economia e Sociologia, possuía ainda um conhecimento teórico espantoso do marxismo. Mas, ao mesmo tempo, era um homem muito forte em matemática. Havia nele uma conciliação entre os modelos da Geografia Quantitativa e a Teoria Marxista. As duas coisas não são tão antagônicas! 
GEOSUL - A revista Finisterra, criada no CEG/UL pelo Prof. Orlando Ribeiro na década de 1960, é a grande referência histórica que se tem na difusão de ideias geográficas em Portugal a partir de Lisboa. Diga-nos um pouco da trajetória desse periódico e como ele se encontra na atualidade.

Prof. Jorge Gaspar - Nos anos 1980 fiz uma análise das publicações, para ver as mudanças que ocorreram. Depois disso não fiz nada de sistemático e assim não posso responder. $\mathrm{O}$ que posso dizer é que a Geografia da Finisterra é uma Geografia com ambição e que tem qualidade. Mas há um problema, pois hoje é difícil para uma revista se projetar com o sincretismo, onde há uma mistura de temas. Assim, alguns colegas, nos últimos anos, têm optado por fazer números temáticos. Uns se saem melhor, outros não tão bem, mas é uma ideia. Já se chegou a pensar em fazer duas séries. É uma grande ambição que daria muito trabalho, mas eu penso que teria sido bom, termos feito assim. Seria uma série mais ligada às questões ambientais, à Geografia Física; e outra às Ciências Sociais, incluindo questões econômicas, políticas, etc. Creio que é uma questão ainda em aberto. Nos últimos anos a Finisterra tem, qualitativamente, melhorado muito. A diretora, Maria João Alcoforado, tem feito um grande esforço no sentido de internacionalizar a revista. Ela foi sempre internacional e, desde o número um, teve autores e geógrafos de todo o mundo a colaborar: espanhóis, americanos, ingleses, brasileiros, etc. Mas ainda não é de uma forma sistemática e estruturada no sentido de se colocar na frente.

GEOSUL - Mas isso eu acho que é um pouco da maioria das revistas. Se não, elas não sobrevivem.

Prof. Jorge Gaspar - Eu sei e insisto, nos últimos anos melhorou muito. É interessante isso. A primeira coisa, que já te disse, é em relação aos números temáticos. Não é o essencial, mas é importante e o mais importante foi o papel dos pareceristas especialistas, que têm contribuído para uma qualidade média, sobretudo para não haver certo "incesto" dentro da revista. Outro 
ponto importante é o fato de a revista estar toda online. Isto é positivo.

GEOSUL - O senhor, nas suas relações com geógrafos brasileiros, teve contatos com ideias e estudiosos como, dentre outros, o Prof. Milton Santos, que o considerava como seu padrinho. Fale-nos um pouco como foi essa relação profissional e afetiva com aquele que foi e é uma das mais importantes referências na Geografia, não apenas brasileira, mas para significativa parcela de estudiosos e intelectuais que se interessam pelas sociedades do chamado Terceiro Mundo.

Prof. Jorge Gaspar - E do Primeiro Mundo também.

GEOSUL - Aqui na Europa ele é meio esquecido.

Prof. Jorge Gaspar - Não. Eu estou lendo uma tese de uma cidadã argentina, apresentada na Universidade de Bauhaus, em Weimar. Ao olhar a bibliografia vemos o Santos, no meio de alemães, ingleses e americanos. Milton Santos é, talvez, um dos nomes mais referenciados.

GEOSUL - Mas deve ser uma exceção este trabalho.

Prof. Jorge Gaspar - Ela é argentina, tem um doutoramento na Argentina também. Este é seu segundo doutoramento. Enfim, ele é conhecido, sobretudo na França, onde ele é mais referenciado. Depois é em Portugal. Curiosamente, ele talvez seja mais referenciado no âmbito da Sociologia.

GEOSUL - Andei pesquisando a revista do ICS (Análise Social) e, grosso modo, não encontrei uma referência textual a Milton Santos.

Prof. Jorge Gaspar - Mas se procurar nas publicações do CES de Coimbra você encontra. O CES, inclusive, instituiu com a CAPES a cátedra Milton Santos.

Conheci o Milton numa visita que ele fez a Lisboa, quando ainda eu era estudante. E depois nos encontramos em congressos e na França 
mais de uma vez. Mas a nossa relação se desenvolve depois dos "25 de Abril", e, sobretudo, depois do retorno da democracia ao Brasil, quando ele volta ao seu país. Encontramo-nos primeiramente em Salvador e no Rio de Janeiro. E assim estabelecemos uma relação afetiva. Aprendi coisas com ele, e procurei me beneficiar de seu pensamento, que nem sempre é fácil, embora convergisse com as linhas em que eu trabalhava. Só que ele tinha um enfoque essencialmente teórico, no sentido de procurar construir uma epistemologia geográfica. E no fundo é um homem de modelos. O pensamento dele, como o de Orlando Ribeiro, é um pensamento modelista, ou seja, que buscava simplificar a realidade. Ele desenvolveu um supermodelo através de sucessivos aperfeiçoamentos, para deixar o essencial e consegue fazer isso de uma forma literária, no sentido da escrita, conseguindo assim ser rigoroso, verbalizando os seus modelos; embora eu ache que a Geografia dele poderia beneficiar do que é a linguagem modelista por excelência da Geografia: o mapa. Ele usa pouco o mapa.

GEOSUL - Ele dizia que isso é ferramenta.

Prof. Jorge Gaspar - Pois é. E como ele chegava lá? Na sua cabeça ele conseguia traduzir aquilo tudo em palavras. Mas ele poderia recompor aqueles modelos mais geográficos, no sentido de serem mais cartográficos. $\mathrm{E}$ isto teria lhe dado ainda uma maior projeção, nomeadamente no mundo anglo-saxônico, onde de resto é bem conhecido e referenciado.

GEOSUL - Mas é muito mais na América Latina.

Prof. Jorge Gaspar - Isso é verdade; mas o Prêmio Vautrin Lud que the foi conferido em 1994, partiu, de acordo com o regulamento, de um número significativo de nomeações provenientes de instituições europeias e americanas da área da Geografia.

No âmbito da Geografia Econômica e Social, mormente nos temas do desenvolvimento, a obra de Milton Santos é sobejamente reconhecida. 
GEOSUL - O senhor diz aqui em Portugal?

Prof. Jorge Gaspar - Não só. Em todo o espaço da Geografia, inclusive nesse Terceiro Mundo que não é tão Terceiro Mundo, pois quando se chega à universidade não há Terceiro Mundo; só há um mundo. As dificuldades começam quando se verifica quase uma obrigação de citar o Milton Santos: "como diz Milton Santos...” Depois se passa à frente.

GEOSUL - Vira um modismo.

Prof. Jorge Gaspar - Exatamente. É quase uma "moda", e isto não é bom. O trabalho da Maria Adélia Aparecida de Souza foi muito importante para descodificar, para apontar às pessoas uma maneira de trabalhar sobre a obra dele. Não recordo qual pesquisador francês falava de uma entronização do Milton Santos; uma sacralização. E quando um cientista é sacralizado, estamos prejudicando sua obra.

GEOSUL - Quem o senhor acha que foi responsável por isto?

Prof. Jorge Gaspar - Não houve um responsável. Isto é do império acadêmico. Mas o que é fato é que, mesmo em nível mundial, um geógrafo como Milton Santos é diferente.

GEOSUL - Por ser negro e terceiro-mundista?

Prof. Jorge Gaspar - Não. Eu digo no sentido do seu pensamento e da obra que ele deixou.

GEOSUL - Mas eu digo no sentido de que ele se superava pela obra.

Prof. Jorge Gaspar - Eu não gosto muito desta abordagem. Isto é usar teorias que estão ultrapassadas para interpretarmos o sucesso ou a qualidade científica, levando em questão que era a negritude dele que o levava a aprofundar... 
GEOSUL - Não estou colocando por este viés determinista. Mas é no sentido de ser uma pessoa de Terceiro Mundo, que não estava muito acreditando naqueles modelos europeus ou americanos, e que desenvolveu uma geografia radical, como ele propõe.

Prof. Jorge Gaspar - Não sei se é tão diferente assim. Há outros brancos a fazer o mesmo.

GEOSUL - Tinham e faziam. Mas o Milton se destacava e talvez criasse uma diferenciação.

Prof. Jorge Gaspar - Não sei. Eu o acho muito rico e muito da riqueza dele está na linguagem e na forma de abordar. Se tivesse usado, no método dele, mais modelos gráficos e cartográficos, ele seria mais conhecido mundialmente, e, na verdade, mais acessível.

GEOSUL - O senhor acha que o texto dele gera um discurso difícil?

Prof. Jorge Gaspar - Muito rico e difícil. O discurso dele tem uma coisa que não é frequente, oferece várias orientações. Em geral as pessoas só seguem uma, que é aquela que tem uma produção imediata, que é a que vem a ser base de certo tipo de ação contra o capital e o Estado/poder técnico. O que ele diz a propósito da importância da técnica como um fator de domínio e subjugação é interessante para se ver outras coisas.

GEOSUL - Atualmente, mesmo sendo aposentado, o senhor continua a atuar profissionalmente, notadamente em atividades ligadas com o planejamento. Comente como esse tema e as atividades se manifestaram em suas práticas profissionais e se elas foram importante influência para o surgimento do IGOT (Instituto de Geografia e Ordenamento do Território), na Universidade de Lisboa e, na mesma perspectiva, como um referencial para outras instituições de ensino superior em Portugal, que também passaram a criar cursos com essas nomenclaturas, a partir de reformas universitárias orientadas por Bolonha, onde a Geografia parece assumir mais um caráter técnico do que acadêmico. 
Prof. Jorge Gaspar - De fato, creio ter contribuído para a afirmação do geógrafo enquanto profissional no planejamento e no ordenamento do território e hoje procuro manter-me atento e dar os meus contributos, sobretudo no âmbito do CEDRU, mas também através do IGOT, cujo conselho científico teve a maior atenção em relação à minha pessoa, ao propor-me para Professor Emérito da Universidade de Lisboa, o que foi aprovado pela Reitoria.

Acho que devo muito da minha orientação e trabalho no planejamento e ordenamento do território a duas situações: a primeira foi ter ido atuar na Arquitetura, no momento em que os arquitetos alargaram a sua escala e a sua metodologia de intervenção; a segunda foi a minha estadia na Suécia, pois lá, então, muitos geógrafos, entre os quais Hägerstrand, estavam a lançar um grande projeto nacional relacionado com o processo de urbanização. Este projeto implicou, por exemplo, concentrar hospitais e fazer novos esquemas rodoviários e de aeroportos para o país. E eu vivi isso. Houve uma concentração de municípios, que passaram de 800 para 270 . E houve também grandes problemas. Hägerstrand escreveu um artigo mais tarde, como que se autocriticasse, sobre alguns aspectos dessa iniciativa, entre outras. Enfim, ter vivido isto foi muito importante, e acabei por trazer isto para cá, pois vivi lá as mudanças tecnológicas da Geografia, a emergência do SIG, de cartografia por computador, das bases de dados. Tudo isto estava sendo feito lá. Escrevi um artigo sobre esse momento e não havia palavras em português para certas ideias para as quais eu só conhecia as suas denominações em sueco ou em inglês.

A criação recente do IGOT foi outra questão. A ideia de criar um instituto de Geografia autônomo foi, primeiramente, e há muitos anos, de Ilídio do Amaral. Ele chegou a falar em uma reunião do nosso conselho interno do CEG e inclusive desenhou um edifício. Esta ideia de autonomização, que a Geografia deverá aproveitar, pode proporcionar uma interação forte com outras áreas do conhecimento, como a Engenharia, a Arquitetura, a Economia, a Geologia, a Oceanografia, a Cartografia. 
GEOSUL - Uma espécie de "Engenharia Geográfica"...

Prof. Jorge Gaspar - Não exatamente. Agora, já temos muitos geógrafos-geógrafos. Eu, como militar, sou de engenharia, sou topógrafo-cartógrafo e também já ensinei Engenharia do Território, no IST, uma Escola de Engenharia, mas no caso do IGOT trata-se de Geografia: ensino, investigação, aplicação.

GEOSUL - Como o senhor avalia, hoje, a formação universitária em Geografia em Portugal e quais são, no seu entender, as principais temáticas e nomes de profissionais que estão a influenciar as atuais gerações de alunos e futuros profissionais, originários deste campo do saber? A Geografia em Portugal tem hoje, no seu entender, relevância e perspectiva de contribuições transdisciplinares acadêmicas; práticas profissionais como em planejamento ou para o ensino escolar?

Prof. Jorge Gaspar - A sua questão não pode ser respondida no âmbito de uma entrevista, pois implica pesquisa, análise, que não está feita. Fizemos isso para os anos 80 e 90 do século passado, mas para os nossos dias ainda não está feito. O que posso dizer é que hoje há um número maior de domínios relevantes na geografia portuguesa e bem assim de geógrafos de gabarito nesses domínios, que decerto estão a marcar as futuras gerações.

Minha avaliação é que a formação universitária em Geografia, em Portugal, não está mal. Está bem! Tem o mesmo nível das melhores escolas da Europa. Eu sempre disse isto aos meus colegas mais novos e eles não levavam a sério. Eu dizia nos anos 1980 que a nossa escola de Geografia podia ser a melhor da Europa. E era quase. A única pessoa que concordava comigo era o Horácio Capel. Mas nós não levamos isso muito a sério. Quando foi feito aquele inquérito ao nível da Europa, pelo Libération, eles apontavam isso. Acho que nós não fizemos por manter esta competitividade. Agora, em alguns domínios - não estou a par de tudo - está se avançando. Tem-se feito coisas importantes dentro da Geografia, no domínio das aplicações, e também do desenvolvimento teórico do saber. Um exemplo é o estudo das migrações, que é uma área que tem chamado 
a atenção, em particular com os estudos de Lucinda Fonseca e das suas equipas.

Outra área é a do ordenamento do território, que fez com que a Geografia ganhasse um peso muito grande, tanto em nível nacional como europeu, onde demos contribuições importantes. E tem sido nestas aplicações que se tem conseguido praticar a integração dos saberes geográficos: da Climatologia onde a Maria João Alcoforado promoveu estudos de grande interesse para o planejamento; da Geomorfologia com importantes contributos para a resolução do problema dos riscos naturais, destacando nomes como J.L. Zêzere e Ana R. Pereira em Lisboa, Fernando Rebelo em Coimbra, Ana Monteiro no Porto ou ainda Maria José Roxo na Universidade Nova de Lisboa; na Geografia Econômica e Desenvolvimento e Ordenamento há também um número de profissionais de valor como José Manuel Simões e Mário Vale, no IGOT, Margarida Pereira na Nova de Lisboa, Rio Fernandes no Porto; na Geografia Urbana além deste último temos como exemplos, Miguel Bandeira na Universidade do Minho, Fernanda Cravidão em Coimbra, Eduarda Costa em Lisboa e, claro está, Teresa Barata Salgueiro e a sua equipa também no IGOT; na Geografia Social e Cultural destaco alguns nomes, Paula Santana, de Coimbra, na Geografia da Saúde; Isabel André, Jorge Malheiros, Eduardo Brito Henriques, no IGOT, João Sarmento e Ana Francisca Azevedo na Un. do Minho e Lucinda Fonseca com sua equipa no estudo das migrações e diálogos interculturais; por último uma referência aos SIG, cujo progresso foi patente nas duas últimas décadas e onde devo realçar o José António Tenedório, da Universidade Nova de Lisboa. Claro que esta lista, não pretende ser exaustiva nem hierarquizadora, são os nomes que me ocorreram nesta conversa... e abrangem apenas algumas escolas de Geografia. Note-se que o ensino da Geografia tem também algum peso nas faculdades de Arquitetura de Lisboa e do Porto, devendo ainda lembrar que tanto na administração pública como em empresas privadas se pratica Geografia de excelente qualidade.

Conseguiremos manter esta posição? É complicado. Daí vem a importância de se investir no âmbito interdisciplinar, com as 
pessoas, trabalhando conjuntamente. Eu colocaria em primeiro lugar as pessoas da Engenharia e, portanto, o IGOT já promove uma interação forte com esta área do saber. Refiro-me aqui aos vários setores da Engenharia, inclusive a informática - que é muito importante. Nós temos essa competência no Centro de Estudos Geográficos, com o Diogo de Abreu e os seus discípulos; ele é um homem que sabe muitíssimo matemática, professor catedrático, ele me sucedeu como diretor do CEG. Com ele tivemos no final dos anos 1980 e início dos 1990 uma parceria com a Engenharia Civil, muito avançada no tempo, que consistia em formar bases de dados para análise regional. Ainda hoje vale a pena visitar o que se escreveu sobre isto, e então trabalhamos com os nossos melhores informáticos da época, há um quarto de século. Há outra área que tenho que esperar para tirar maiores conclusões, devido a certo aspecto modista: a Geografia Humanista. Ela está relacionada com toda a problemática gerada pelo ambiente pós-colonial. Um rapaz que é professor da Universidade do Minho, investigador do CEG, e que se doutorou na Irlanda, em Cork, tem feito trabalhos interessantes neste domínio. Esperamos que ele aprofunde e não se disperse. $\mathrm{O}$ nome dele é João Sarmento e lançou agora um livro muito interessante, com o prefácio do Paul Claval. Ele se situa dentro de uma Geografia Humanista pós-colonial, e se aproxima em certos pontos do Milton Santos.

GEOSUL - Mas eu senti uma grande ausência do discurso do Milton, hoje, no IGOT.

Prof. Jorge Gaspar - Mas isto está relacionado com duas coisas: pelo lado da Geografia francesa tradicional, pessoas como Suzanne Daveau, Orlando Ribeiro ou mesmo Carlos Medeiros, que eram de grande qualidade e muito influentes, não apreciaram devidamente a obra do Milton. E, depois, porque os marxistas vinham de outras escolas. Alem disso, não tinha uma aplicação visível, e nós aqui somos muito sensíveis a isso, à aplicação! 
GEOSUL - Sentimos que há sempre uma afirmação desse empirismo, no sentido de aplicação, e que se acha que a Geografia Miltoniana é muito teórica. Mas é também muito prática...

Prof. Jorge Gaspar - Isso digo eu. Eu sempre disse para que se lesse e se constatasse a importância, por exemplo, desta questão das técnicas.

GEOSUL - O senhor não acha que esta supervalorização do profissional para ser um técnico desprestigia a parte do magistério? Prof. Jorge Gaspar - Sim. As pessoas pensam que isto dá mais status, mas estão erradas. Sou uma das pessoas que tem culpa em relação a isto. Mas estou me redimindo, pois faço muitas ações em escolas. Amanhã, às quinze horas, vou ter uma reunião numa escola de magistério, de professores primários e educadores de infância. Convidaram-me - o e-mail que me enviaram é muito bonito - cinco alunos deste curso, de uma escola de prestígio, escreveram-me dizendo que estão fazendo um trabalho sobre a minha vida, e se poderia comparecer à escola. Enfim, vou lá amanhã, e dou muita importância a isto. Mas havia a necessidade disso, pois falar de Geografia era falar de professores do Liceu, e mais nada. "O senhor será professor do Liceu"? Sempre ouvi isso. $\mathrm{Eu}$ gosto, mas era muito mais prestigioso ir trabalhar com uma equipe de arquitetos, do que dar aulas no Liceu. Neste ponto, a Associação dos Professores de Geografia tem feito um trabalho meritório, mas poderia ter sido mais ambiciosa.

GEOSUL - O senhor comentou nesta nossa longa conversa, rica, que foi um curso pra mim... O senhor tem notícias ou acompanhado o desempenho de práticas de geógrafos em diferentes lugares do planeta? Que referências (nomes e temáticas tratadas) o senhor destacaria?

Prof. Jorge Gaspar - Posso ir citando os nomes, mas posso estar ultrapassado e de novo não há espaço... Veja, em muitos países da Europa há gente com muito valor e interesse, cuja ação ultrapassa as fronteiras dos respectivos países. Por exemplo, hoje, na Suécia, 
eu destaco o Sture Öberg, da minha geração, teve um papel muito importante tanto na universidade quanto na política da Suécia. Hoje continua a desempenhar um papel relevo na Europa, colaborando com a ERC que é um órgão muito original da União Europeia; e participa ativamente em iniciativas da Academia Europeia. Já falei de vários franceses, que são sempre importantes, em diferentes áreas, como o Antoine Bailly, na ponte para a Ciência Regional, o Jacques Lévy, o Paul Claval, que, com aquela idade, continua produzindo muito e interessante.

GEOSUL - O senhor conheceu o Professor Michel Rochefort?

Prof. Jorge Gaspar - Muito bem. O nosso conhecimento começou através de um aluno de doutoramento que no início de 1970 veio para Lisboa preparar uma dissertação de $3^{\circ}$ Ciclo, o François Benhamou. O nosso relacionamento aprofundou-se a partir do 25 de Abril de 1974, abrangendo a Regina. Continua a ser um marco no urbanismo e na geografia urbana francesa.

GEOSUL - E o David Harvey?

Prof. Jorge Gaspar - Conheço bem a sua obra, que continuo a visitar, tanto na fase da nova geografia, como nas orientações marxistas; mas não o conheço pessoalmente.

\section{GEOSUL - E o Horácio Capel?}

Prof. Jorge Gaspar - Ele é um homem formidável. Ele fez um trabalho extraordinário em prol da Geografia em geral, e da América Latina especificamente. Além de amigo, é uma referência que continua a acompanhar-me. Ainda temos uns projeto para levar a cabo em conjunto, talvez em Alvito.

GEOSUL - O senhor conheceu o Professor Carlos Augusto de Figueiredo Monteiro, que trabalha com a linha da "climatologia aplicada"?

Prof. Jorge Gaspar - Eu sei quem é, mas acho que não o conheci pessoalmente. 
GEOSUL - Em linhas gerais, que mensagem o senhor daria para um aluno secundarista que desejasse fazer um curso universitário em Geografia? E por quais sugestões de temáticas e/ou atividades o senhor recomendaria para esse futuro profissional buscar em sua formação e se dedicar em campos de trabalho?

Prof. Jorge Gaspar - Primeiramente, é fazê-lo acreditar que a Geografia é um domínio importante. A pior coisa que há com os geógrafos mais velhos, e que passam esta doença aos mais novos, é considerá-la como uma disciplina secundária. A mensagem que eu daria, é que só se vá para Geografia se acreditar que é um domínio científico e técnico importante. Geography matters, a expressão da Doreen Massey que percorre o mundo, já adaptada a outras coisas, é fundamental. Acreditar que a Geografia é importante. Eu sempre vi a Geografia como o melhor curso do mundo. As temáticas que recomendaria, as básicas são as três que estão naquele esquema do Peter Haggett. Ele não é um homem de inovação, mas foi um sistematizador fantástico. Os três conjuntos das ciências e localizar a Geografia ali num ponto. A Geografia pode ser tudo, pode cair para qualquer um dos lados. E este pensamento geométrico é importante. O Erastóstenes antes de ser geógrafo, era geômetra. Primeiro há que medir a Terra, e depois é que se vai descrevê-la, e depois ainda, se for preciso, é que vamos fazer a Terra. Portanto, são os básicos, e a ambição que eu não consegui foi dar uma formação básica para a Geografia. As línguas - sobretudo o português, a língua própria -, mas antes delas a Matemática. Para escrever como o Milton Santos é preciso muita prática. Nós empenhamos no primeiro ano, e os alunos detestavam fazer testes surpresa de quinze minutos. Eles ficavam em pânico. No teste, que era só uma questão, eles tinham que escrever uma ou duas páginas. É fundamental por os alunos jovens a não terem medo do papel em branco e botá-los a pensar.

GEOSUL - O senhor provocava medo em seus alunos?

Prof. Jorge Gaspar - Antes respeito, pela importância e relevância dos saberes geográficos. Mas depois contávamos tanta piada, ou eles falavam, e saíamos todos contentes. Portanto, o que 
eu diria aos alunos é considerarem que as coisas mais importantes são a Matemática e a língua materna. Mas também as outras línguas, pois as línguas são o pensamento. Outra coisa que senti mais carência na minha formação e que tentei suprir - não foi a matemática, pois eu tinha uma preparação boa do ginásio, mas a Filosofia. O básico, o essencial da Filosofia é aquilo que é o mais difícil recuperar.

GEOSUL - Professor, agradecemos muito a sua atenção e a disponibilidade em nos conceder esta entrevista. Uma grande aula! 